\title{
Penerapan Metode Statistical Processing Control Untuk Menganalisis Pengendalian Kualitas Produk pada PT. Asera Tirta Posidonia, Kota Palopo
}

\section{Didiharyono D.}

Universitas Andi Djemma palopo

Email: muh.didih@gmail.com

\begin{abstract}
Abstrak
Penelitian ini bertujuan untuk menganalisis penerapan metode Statistical Processing Control (SPC) dalam pengendalian kualitas sebagai upaya menekan jumlah produk cacat dan mengidentifikasi faktor-faktor apa saja yang menyebabkan kerusakan/ cacat produk yang diproduksi oleh PT. Asera Tirta Posidonia. Penelitian ini merupakan penelitian kuantitaf dengan data sekunder. Langkah-langkah analisis data dengan menggunakan metode SPC yaitu (1) Mengumpulkan data produksi dan produk rusak (check sheet). (2) Membuat histogram, (3) membuat grafik kendali $u$ (u-chart). (4) Mencari faktor penyebab kerusakan/ kecacatan dengan diagram sebab-akibat, dan (5) membuat rekomendasi/ usulan perbaikan kualitas. Penelitian ini dapat disimpulkan dengan melihat grafik kendali u (u-chart) yang menyatakan bahwa kualitas produk berada diluar batas kendali (statistics out control). Hal tersebut menunjukkan masih ada titik-titik yang berada diluar batas kendali yang merupakan indikasi bahwa proses berada dalam keadaan masih mengalami penyimpangan. Hasil analisis diagram fishbone dapat diketahui faktor penyebab kerusakan dalam proses produksi, yaitu berasal dari faktor pekerja, mesin produksi, metode kerja, material/ bahan baku dan lingkungan kerja. Oleh karena itu, semua penyebab kerusakan dapat segera diperbaiki atau pencegahan sedini mungkin agar tidak terjadi kerusakan yang lebih besar lagi.
\end{abstract}

Kata Kunci: Statistical Processing Control dan Pengendalian Kualitas Produk

\begin{abstract}
This study aimed to analyze the application of Statistical Processing Control (SPC) methods in quality control an effort to reduce the number of defect products and identify of factors are causing the defect products manufactured by PT. Asera Tirta Posidonia. This research is a quantitative research with secondary data. Step analysis of the data using the SPC, namely (1) to collect data on production and the defect product (check sheet). (2) Make a histogram, (3) make a graph control $u$ (u-chart). (4) Finding the causes of damage / disability by causeeffect diagram, and (5) make recommendations quality improvement. This research can be concluded with a look at the graph of control $u$ (u-chart), which states that the quality product are beyond the control limit (statistics out control). It shows there are still points that are outside the control limit that an indication the process is in a state still experiencing irregularities. Analysis results of Fishbone diagram can be known factors causing damage in the process of production, which is derived from the factor workers, production machinery, work methods, materials / raw materials and environment. Therefore, all the causes of the damage can be fixed or prevention as early as possible in order to avoid greater damage.
\end{abstract}

Keywords: Statistical Processing Control and Quality Control Products 


\section{PENDAHULUAN}

Setiap industri memastikan sistem perusahan berjalan dengan baik dan berusaha menjaga agar produk yang dihasilkan mampu memenuhi keinginan dan kepuasan konsumen. Hal ini mendorong perusahaan untuk lebih meningkatkan kualitas produk yang dihasilkan sesuai dengan standar dan spesifikasi yang telah ditentukan. Pengendalian kualitas dengan metode Statistical Processing Control (SPC) sering diterapkan oleh perusahaan dalam pengendalian kualitas produk. Pengendalian kualitas produk merupakan suatu sistem pengendalian yang dilakukan dari tahap awal suatu proses sampai produk jadi, bahkan sampai pada pendistribusian produk pada konsumen.

Suatu perusahaan tidak bisa lepas dari permintaan konsumen akan produk yang dihasilkannya. Setiap konsumen menginginkan bahwa barang yang diperolehnya dakam kondisi yang baik serta terjamin kualitasnya. Oleh karena itu, perusahaan harus menjaga agar kualitas produk yang dihasilkan terjamin mutunya serta dimiliki oleh konsumen dan diterima dipasar. Pengendalian kualitas pada perusahaan baik perusahaan jasa maupun perusahaan manufaktur sangatlah diperlukan. Dengan kualitas jasa ataupun barang yang dihasilkan tentunya perusahaan berharap dapat menarik konsumen dan dapat memenuhi kebutuhan serta keinginan konsumen.

Pengendalian kualitas yang dilaksanakan dengan baik akan memberikan dampak terhadap mutu produk yang dihasilkan oleh perusahaan. Kualitas dari produk yang dihasilkan oleh suatu perusahaan ditentukan berdasarkan ukuran-ukuran dan karakteristik tertentu. Walaupun proses-proses produksi telah dilaksanakan dengan baik, namun pada kenyataan masih ditemukan terjadinya kesalahan-kesalahan dimana kualitas produk yang dihasilkan tidak sesuai dengan standar atau dengan kata lain produk yang dihasilkan mengalami kerusakan atau cacat pada produk.

Produk yang berkualitas akan memberikan keuntungan bagi produsen dan juga memberikan kepuasan bagi para konsumen. Dengan memberikan perhatian tentang kualitas maka akan memberikan dampak positif bagi produsen (perusahaan). Dimana kualitas yang baik dapat meningkatkan permintaan sehingga meningkat pula hasil penjualan dan dapat menambah pendapatan produsen. Kualitas produk yang baik dihasilkan dari proses pengendalian kualitas yang baik pula. Maka banyak perusahaan yang menggunakan metode tertentu untuk menghasilkan suatu produk dengan kualitas yang baik. Oleh karena itu, pengendalian kualitas dibutuhkan untuk menjaga agar produk yang dihasilkan sesuai dengan standar kualitas yang berlaku.

Produk yang dihasilkan oleh PT. Asera Tirta Posidonia salah satunya adalah Air Minum dalam Kemasan (AMDK) CUP 220 ML. AMDK tersebut dikemas dan dipasarkan untuk memenuhi kebutuhan konsumen. AMDK dihasilkan dengan melewati suatu proses yang disebut proses produksi. Proses produksi adalah proses yang dilakukan dalam menentukan hasil (output) dari kualitas suatu produk. Ketika proses mengalami masalah atau proses tidak terkendali (statistics out control) maka hasil yang didapat tidak akan sesuai dengan target yang diinginkan. Begitupula sebaliknya, bila proses yang dilakukan sudah terkendali (statistics in control) maka akan menghasilkan output yang berkualitas dan sesuai dengan yang diharapkan.

Berdasarkan penjelasan di atas maka penulis meneliti Penerapan Metode Statistical Processing Control untuk Menganalisis Pengendalian Kualitas Produk Pada PT. Asera Tirta Posidonia. Perusahan tersebut merupakan salah PT. yang berada di Kota Palopo yang bergerak memproduksi air bersih dalam kemasan. Penelitian ini bertujuan untuk menganalisis penerapan metode SPC dalam pengendalian kualitas sebagai upaya menekan jumlah produk 
cacat dan mengidentifikasi faktor-faktor apa saja yang menyebabkan kerusakan/ cacat produk yang diproduksi oleh PT. Asera Tirta Posidonia.

\section{TINJAUAN PUSTAKA}

\section{Kualitas}

Kualitas merupakan suatu istilah yang berkaitan dengan mutu suatu barang/ jasa. Ditinjau dari pandangan konsumen, biasanya mereka mengatakan bahwa kualitas adalah sesuatu yang cocok dengan selera. Produk dikatakan berkualitas apabila produk tersebut mempunyai kecocokan penggunaan bagi dirinya dan bermanfaat bagi orang lain. Pandangan lain mengatakan kualitas adalah barang atau jasa yang dapat menaikkan status pemakai. Ada juga yang mengatakan barang/ jasa yang memberikan manfaat pada pemakai (measure of utility and usefulness). Sebagaimana Arini (2007) yang mendefinisikan kualitas sebagai kemampuan dari suatu produk atau jasa yang secara konsisten memenuhi harapan dari konsumen.

Kualitas juga diartikan sebagai keseluruhan ciri dan karateristik produk atau jasa yang kemampuannya dapat memuaskan konsumen. Istilah kebutuhan diartikan sebagai spesifikasi yang tercantum dalam kontrak maupun kriteria-kriteria yang harus didefinisikan terlebih dahulu. Kualitas merupakan segala sesuatu yang memenuhi keinginan atau kebutuhan pelanggan. Kualitas juga berarti kecocokan penggunaannya (Montgomery, D.C., 2008).

\section{Pengendalian Kualitas}

Pengendalian kualitas merupakan salah satu eknik-teknik dalam memantau dan peningkatkan performansi untuk menghasilkan produk yang berkualitas (Triadji, 2007). Tujuan utama pengendalian kualitas adalah untuk mendapatkan jaminan bahwa kualitas produk atau jasa yang dihasilkan sesuai dengan standar kualitas yang telah ditetapkan dengan mengeluarkan biaya yang ekonomis atau serendah mungkin. Pengendalian kualitas dilakukan agar dapat menghasilkan produk berupa barang/ jasa yang sesuai dengan standar yang diinginkan dan direncanakan, serta memperbaiki kualitas produk yang belum sesuai dengan standar yang telah ditetapkan dan sebisa mungkin mempertahankan kualitas yang sesuai.

Adapun tujuan dari pengendalian kualitas menurut Sofjan (1998) adalah 1). Agar barang hasil produksi dapat mencapai standar kualitas yang telah ditetapkan. 2). Mengusahakan agar biaya inspeksi dapat menjadi sekecil mungkin. 3). Mengusahakan agar biaya desain dari produk dan proses dengan menggunakan kualitas produksi tertentu dapat menjadi sekecil mungkin. 4). Mengusahakan agar biaya produksi dapat menjadi serendah mungkin.

\section{Metode Statistical Processing Control}

Statistical Processing Control (SPC) merupakan sebuah teknik statistik yang digunakan secara luas untuk memastikan bahwa proses memenuhi standar. Dengan kata lain, selain SPC merupakan sebuah proses yang digunakan untuk mengawasi standar, membuat pengukuran dan mengambil tindakan perbaikan selagi sebuah produk atau jasa sedang diproduksi (Taneja, 2013). Menurut Gerald Smith (2003) bahwa SPC merupakan kumpulan dari metode-metode produksi dan konsep manajemen yang dapat digunakan untuk mendapatkan efisiensi, produktivitas dan kualitas untuk memproduksi produk yang kompetitif dengan tingkat yang maksimum, dimana Statistical Process Control melibatkan penggunaan signal-signal statistik untuk meningkatkan performa dan untuk memelihara pengendalian dari produksi pada tingkat kualitas yang lebih tinggi. 
Tujuan utama penggunaan SPC di dalam suatu proses pengendalian kualitas produk adalah untuk meminimalkan variability, memperbaiki kualitas produk, dan menjaga kestabilan proses. Sedangkan, manfaat SPC yaitu (a) meminimalisasi variasi yang muncul di dalam proses untuk meningkatkan kemampuan bersaing, (b) mengurangi biaya (melalui kegiatan kontrol disetiap tahapan proses), (c) meningkatkanproduktivitas (mengurangi kesalahan/ cacat) dan (d) meningkatkan keterampilan karyawan dalam mengendalikan proses. Adapun tujuh alat dasar yang digunakan dalam SPC meliputi diagram alir (flow chart), diagram pareto (pareto analysis), lembar periksa (check sheet), diagram sebab-akibat (fishbone diagram), diagram batang (histogram), grafik kendali (control chart), dan diagram tebar (scatter diagram) (Montgomery, DC., 2008)

Menurut Sofjan (1998) manfaat/ keuntungan melakukan pengendalian kualitas secara statistik adalah 1). Pengawasan (control), di mana penyelidikan yang diperlukan untuk dapat menetapkan statistical control mengharuskan bahwa syarat-syarat kualitas pada situasi itu dan kemampuan prosesnya telah dipelajari hingga mendetail. 2). Pengerjaan kembali barangbarang yang telah scrap-rework. Dengan dijalankan pengontrolan, maka dapat dicegah terjadinya penyimpangan-penyimpangan dalam proses. Sebelum terjadi hal-hal yang serius dan akan diperoleh kesesuaian yang lebih baik antara kemampuan proses (process capability) dengan spesifikasi, sehingga banyaknya barang-barang dapat dikurangi sekali. 3). Biayabiaya pemeriksaan, karena pengendalian kualitas statistik dilakukan dengan jalan mengambil sampel-sampel dan mempergunakan teknik sampling, maka hanya sebagian saja dari hasil produksi yang perlu untuk diperiksa. Akibatnya maka hal ini akan dapat menurunkan biayabiaya pemeriksaaan.

\section{METODE PENELITIAN}

Penelitian ini merupakan penelitian kuantitaf dengan data sekunder yang diperoleh pada PT. Asera Tirta Posidonia Kota Palopo. Adapun waktu yang dibutuhkan dalam penelitian ini adalah selama 1 (satu) tahun yaitu dimulai pada bulan November 2015 Oktober 2016. Dalam penelitian ini, pengolahan data dilakukan dengan menggunakan alat bantu yang terdapat pada SPC dan untuk membuat grafik charnya digunakan bantuan software Minitab. Adapun langkah-langkah analisis data yang digunakan adalah sebagai berikut :

1. Mengumpulkan data produksi dan produk rusak (check sheet). Data yang diperoleh dari perusahaan terutama data produksi dan data produk cacat kemudian diolah menjadi tabel secara rapi dan terstruktur. Hal ini dilakukan agar memudahkan dalam memahami data tersebut hingga bisa dilakukan analisis lebih lanjut.

2. Membuat histogram agar mudah membaca atau menjelaskan data dengan cepat, maka data tersebut perlu untuk disajikan dalam bentuk histogram yang berupa alat penyajian data secara visual dalam bentuk grafis balok yang memperlihatkan distribusi nilai yang diperoleh dalam bentuk angka.

3. Membuat grafik kendali $u$ (u-chart). Dalam menganalisa data penelitian ini, digunakan grafik kendali $u$ (grafik kendali proporsi kerusakan) sebagai alat untuk pengendalian proses secara statistik. Penggunaan grafik kendali $\mathrm{p}$ ini adalah dikarenakan pengendalian kualitas yang dilakukan bersifat atribut, serta data yang diperoleh yang dijadikan sampel pengamatan tidak tetap dan produk yang mengalami kerusakan tersebut dapat diperbaiki lagi sehingga harus ditolak (reject). Langkah-langkah pembuatan grafik kendali $u$ yaitu sebagai berikut:

- Menghitung garis pusat (center line) yang menunjukan rata-rata jumlah cacat, yaitu dengan menggunakan persamaan: 


$$
\overline{\boldsymbol{u}}=\frac{\sum \boldsymbol{c}_{\boldsymbol{i}}}{\sum \boldsymbol{n}_{\boldsymbol{i}}}
$$

dengan: $\overline{\boldsymbol{u}}$ : Garis pusat, $c_{i}$ : Banyaknya kesalahan pada setiap unit produk pada sampel setiap kali observasi, dan $\sum \boldsymbol{n}_{\boldsymbol{i}}$ : Jumlah dari banyaknya observasi yang dilakukan.

- Menghitung batas kendali, upper control Limit (UCL) dan Low Control Limit (LCL) untuk grafik kendali $u$, yaitu sebagai berikut:

$$
\mathrm{UCL}=\overline{\boldsymbol{p}}+3 \sqrt{\frac{\overline{\boldsymbol{u}}}{n_{i}}} \text { dan } \mathrm{LCL}=\overline{\boldsymbol{u}}-3 \sqrt{\frac{\overline{\boldsymbol{u}}}{n_{i}}}
$$

- Menentukan grafik kendali $u$, dengan tujuan menentukan jumlah cacat dari setiap subgrup yang diperiksa dan amati apakah data tersebut berada dalam batas pengendali atau diluar kendali.

4. Mencari faktor penyebab kerusakan/ kecacatan dengan diagram sebab-akibat. Setelah diketahui masalah utama yang paling dominan dengan menggunakan histogram, maka dilakukan analisa faktor kerusakan produk dengan menggunakan fishbone diagram, sehingga dapat menganalisis faktor-faktor apa saja yang menjadi penyebab kerusakan produk.

5. Membuat rekomendasi/ usulan perbaikan kualitas. Setelah diketahui penyebab terjadinya kerusakan produk, maka dapat disusun sebuah rekomendasi atau usulan tindakan untuk melakukan perbaikan kualitas produk.

\section{HASIL PENELITIAN}

\section{Data Produksi dan Produk Rusak (Check Sheet)}

Pembuatan tabel (Check sheet) ini berguna untuk mempermudah proses pengumpulan data serta analisis. Data produksi yang ditunjukan oleh Tabel 1 yang menunjukan data produksi dan jumlah cacat selama 1 tahun hari kerja yaitu sebanyak 48 minggu beserta presentasenya.

\section{Histogram}

Setelah check sheet dibuat, maka langkah selanjutnya adalah membuat histogram. Histogram ini barguna unutk melihat banyaknya produksi yang cacat dengan menggunakan diagram batang.

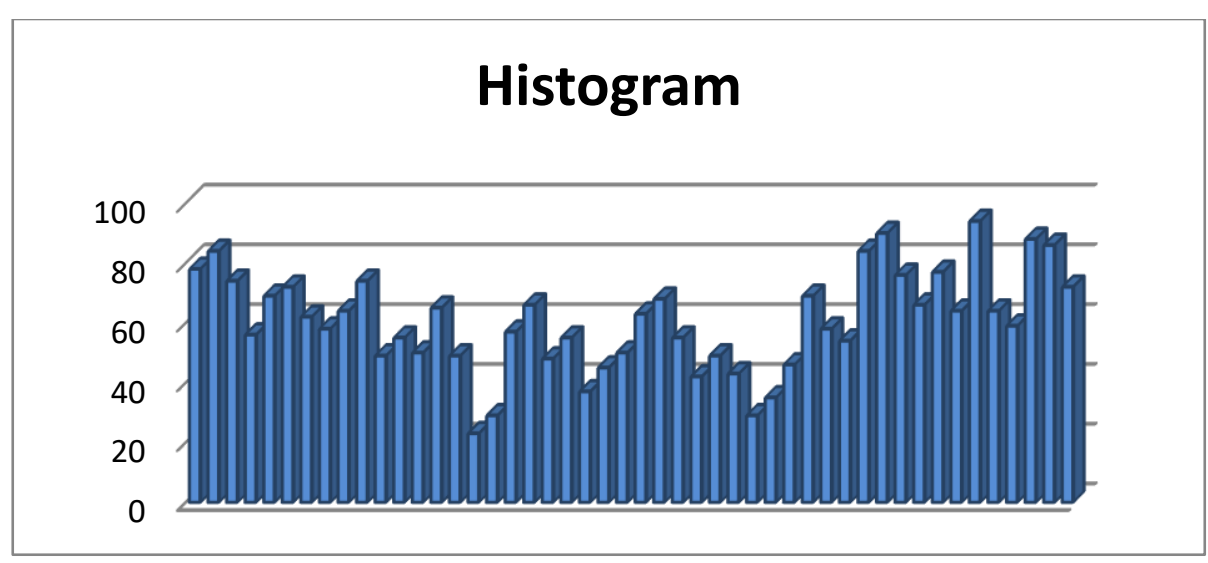

Gambar 1. Histogram

\section{Grafik Kendali $u$ (u-chart)}

Gragik kendali $u$ melukiskan grafik pengendalian untuk ketidaksesuaian dengan ukuran sampel yang konstan dan tidak konstan dengan ukuran unit produk tertentu (Irwan, 2015). Unit pemeriksaan dipilih untuk memudahkan pengumpulan data atau operasional. Berdasarkan data pada Tabel 1 dan persamaan [1] didapatkan: 


$$
\text { Garis pusat } \overline{\boldsymbol{u}}=\frac{\sum \boldsymbol{c}_{\boldsymbol{i}}}{\sum \boldsymbol{n}_{\boldsymbol{i}}}=\frac{2900}{541052}=\mathbf{0}, 00536
$$

Untuk observasi yang pertama dengan sampel 14056 maka batas kendalinya diketahui berdasarkan persamaan [2] yaitu:

$\mathrm{UCL}=\mathbf{0 , 0 0 5 3 6}+3 \sqrt{\frac{\mathbf{0 , 0 0 5 3 6}}{14056}}=0,007212$ dan $\mathrm{LCL}=\mathbf{0 , 0 0 5 3 6}-3 \sqrt{\frac{\mathbf{0 , 0 0 5 3 6}}{14056}}=0,003507$

Untuk observasi yang kedua dengan sampel 14046 lembar maka batas pengendalinya adalah: $\mathrm{UCL}=\mathbf{0 , 0 0 5 3 6}+3 \sqrt{\frac{\mathbf{0 , 0 0 5 3 6}}{14046}}=0,007213$ dan LCL $=\mathbf{0 , 0 0 5 3 6}-3 \sqrt{\frac{\mathbf{0 , 0 0 5 3 6}}{14056}}=0,003506$

Dan seterusnya, sampai pada observasi yang ke-48 dengan sampel 15016, maka batas pengendalinya.

$\mathrm{UCL}=\mathbf{0 , 0 0 5 3 6}+3 \sqrt{\frac{\mathbf{0 , 0 0 5 3 6}}{15016}}=0,007152$ dan $\mathrm{LCL}=\mathbf{0 , 0 0 5 3 6}-3 \sqrt{\frac{\mathbf{0 , 0 0 5 3 6}}{15016}}=0,003567$ Untuk lebih jelasnya ditunjukan oleh Tabel 1 berikut:

Tabel 1. Nilai Batas Atas dan Batas Bawah

\begin{tabular}{|c|c|c|c|c|c|}
\hline No & Produksi & Cacat & Presentase & UCL & LCL \\
\hline 1 & 14056 & 78 & 0,5549232 & 0,007212562 & 0,003507438 \\
\hline 2 & 14046 & 84 & 0,598035 & 0,007213221 & 0,003506779 \\
\hline 3 & 14062 & 74 & 0,5262409 & 0,007212167 & 0,003507833 \\
\hline 4 & 14060 & 56 & 0,398293 & 0,007212299 & 0,003507701 \\
\hline 5 & 11660 & 69 & 0,5917667 & 0,007394016 & 0,003325984 \\
\hline$\cdot$ & $\cdot$ & $\cdot$ & $\cdot$ & $\cdot$ & $\cdot$ \\
$\cdot$ & $\cdot$ & $\cdot$ & $\cdot$ & $\cdot$ & $\cdot$ \\
$\cdot \cdot$ & $\cdot$ & $\cdot$ & $\cdot$ & $\cdot$ & $\cdot$ \\
\hline 46 & 15021 & 88 & 0,5858465 & 0,007152067 & 0,003567933 \\
\hline 47 & 15008 & 86 & 0,5730277 & 0,007152843 & 0,003567157 \\
\hline 48 & 15016 & 72 & 0,4794885 & 0,007152365 & 0,003567635 \\
\hline Jumlah & 541052 & 2900 & & & \\
\hline
\end{tabular}

Sedangkan, grafik kendalinya diplot dengan menggunakan software Minitab, sebagaimana ditunjukan pada Gambar 2 berikut.

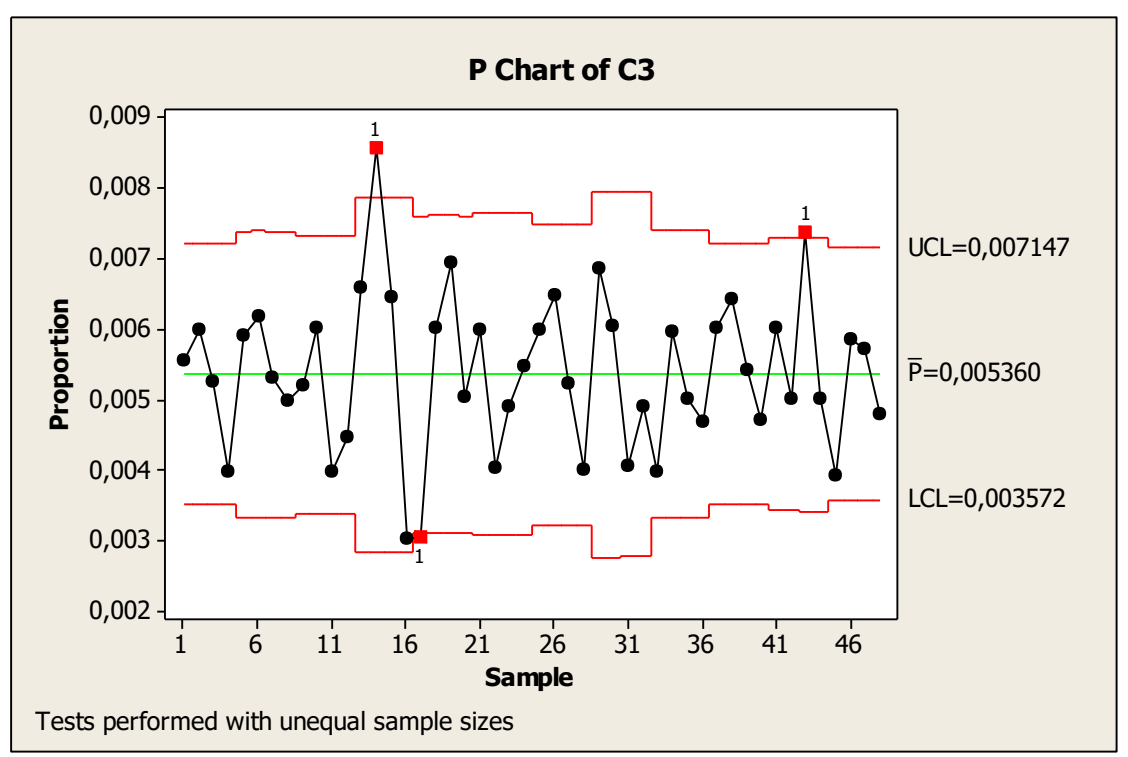

Gambar 2. Grafik Kendali $u$ 
Berdasarkan gambar di atas dapat kita lihat bahwa masih ada titik-titik yang berada diluar batas kendali (UCL dan LCL). Terdapat 3 titik yang berada diluar batas kendali dan 45 titik yang berada didalam batas kendali, sehingga bisa dikatakan bahwa proses tidak terkendali. Karena adanya titik yang berfluktuasi dan tidak beraturan hal ini menunjukkan bahwa pengendalian kualitas untuk produk PT. Asera Tirta Posidonia masih mengalami penyimpangan, oleh sebab itu masih diperlukan analisis lebih lanjut mengapa penyimpangan ini terjadi dengan menggunakan diagram sebab-akibat (fishbone diagram) untuk mengetahui penyebab dari penyimpangan/ kerusakan dari produk tersebut.

\section{Diagram Sebab-akibat (Fishbone Diagram)}

Diagram Fishbone digunakan untuk menganalisis faktor-faktor apa sajakah yang menjadi penyebab kerusakan produk. Adapun faktor-faktor yang mempengaruhi dan menjadi penyebab kerusakan produk secara umum dapat digolongkan sebagai berikut :

1. Pekerja (People), yaitu pekerja yang terlibat langsung dalam proses produksi.

2. Bahan Baku (Material), yaitu komponen-komponen dalam menghasilkan suatu produk menjadi barang jadi.

3. Mesin (Machine), yaitu mesin-mesin dan berbagai peralatan yang digunakan selama proses produksi.

4. Metode (Method), yaitu instruksi atau perintah kerja yang harus diikuti dalam proses produksi.

5. Lingkungan (Environment), yaitu keadaan sekitar tempat produksi baik secara langsung maupun secara tidak langsung mempengaruhi proses produksi.

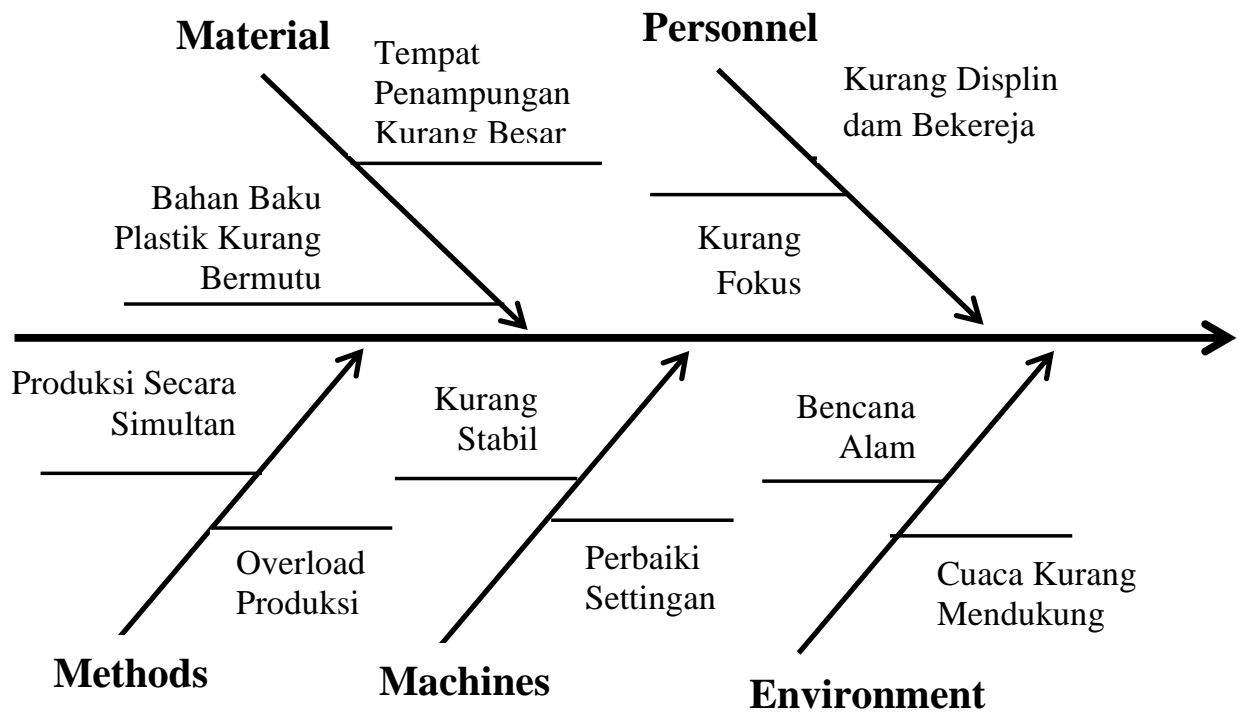

\section{Usulan Tindakan Perbaikan}

Gambar 3. Diagram Fish Bone

Setelah mengetahui penyebab terjadinya penyimpangan/kerusakan pada

produk Koran Harian Tribun Timur, maka disusun suatu usulan tindakan perbaikan secara umum dalam upaya menekan tingkat kerusakan produk.

1. Pekerja (People) yang terlibat langsung dalam proses produksi harus fokus dan displin dalam bekerja. Pimpinan bisa mengadakan pelatihan (tranning) untuk memotivasi semangat kerja.

2. Bahan Baku (Material) sebagai komponen penting dalam menghasilkan suatu produk meliputi bahan baku plastik harus bermutu, tentunya dengan pemeriksaan yang ketat. 
Sementara tempat penampungan harus diperbesar agar memenuhi penampungan air yang akan diproduksi.

3. Pastikan mesin (Machine) yang digunakan selama proses produksi harus tetap stabil dan harus melalukan perbaikan terhadap komponen mesin setiap minggu.

4. Metode (Method) yang dilakukan dalam produksi yaitu melakukan produksi secara simultan (bersama-sama) agar jumlah produk yang dihasilkan sesuai dengan kapasitas.

5. Keadaan lingkungan (Environment) harus kondusif agar para pekerja merasakan kenyaman dalam bekerja.

\section{KESIMPULAN DAN SARAN}

Berdasarkan hasil grafik kendali u (u-chart) dapat dilihat bahwa ternyata kualitas produk berada di luar batas kendali (statistics out control) yang seharusnya. Hal ini dapat dilihat pada grafik kendali yang menunjukkan masih ada titik-titik yang berada di luar batas kendali dan titik tersebut berfluktuasi serta tidak beraturan. Hal ini merupakan indikasi bahwa proses berada dalam keadaan tidak terkendali atau masih mengalami penyimpangan. Hasil analisis diagram fishbone dapat diketahui faktor penyebab kerusakan dalam proses produksi, yaitu berasal dari faktor pekerja, mesin produksi, metode kerja, material/ bahan baku dan lingkungan kerja. Oleh karena itu, semua penyebab kerusakan dapat segera diperbaiki atau pencegahan sedini mungkin agar tidak terjadi kerusakan yang lebih besar lagi.

\section{DAFTAR PUSTAKA}

Ariani, D.W. (1999). Manajemen Kualitas, Yogyakarta: Universitas Atmajaya,

Gaspersz, V. (2005). Pedoman Implementasi Program Six Sigma Terintegrasi dengan ISO 9001:2000, MBNQA, dan HACCP. Jakarta: Gramedia Pustaka Utama.

Irwan, I., \& Haryono, D., (2015). Pengendalian Kualitas Statistik (Pendekatan Teoritis dan Aplikatif). Bandung: PT. Afabeta

Kabir, Md. E., at, all. Productivity Improvement by using Six-Sigma. International Journal of Engineering and Technology. Volume 3 No. 12, December, 2013 . ISSN: 2049-3444

Montgomery, D. C. (2008). Introduction to Statistical Quality Control. New York: John Wiley \& Sons Inc, 2008

Prawirosentono, S. (2007). Filosofi Baru Tentang Manajemen Mutu Terpadu Abad 21 "Kiat Membangun Bisnis Kompetitif". Jakarta: Bumi Aksara.

Sofjan, A. (1998). Manajemen Operasi Dan Produksi. Jakarta : LP FE Universitas Indonesia

Smith, G. M. (2003). Statistical Process Control and Quality Improvement. $5^{\text {th }}$ Edition. USA: Pearson Prentice Hall

Taneja, M., and Manchanda, A. (2013). Six Sigma an Approach to Improve Productivity in Manufacturing Industry. International Journal of Engineering Trends and Technology (IJETT) - Volume 5 Number 6- Nov 2013. ISSN: 2231-5381

Triadji, W. (2007). Perbaikan Kualitas dengan Metode SPC dan Taguchi untuk Mengurangi Cacat Proses Pengepakan Oli Utec 0.8 di PT. Federal Karyatama. Skripsi. Jakarta: Universitas Bina Tama

Western, E. (1956). Statistical Quality Control Hanbook. New York: Western Electric Corporation. Indianapolis, Ind. 